\title{
Fish canning industry wastewater treatment for water reuse - a case study
}

\author{
Raquel O. Cristóvão ${ }^{\mathrm{a}, ~}{ }^{\text {, }}$, Cidália M. Botelho ${ }^{\mathrm{a}}$, Ramiro J.E. Martins ${ }^{\mathrm{a}, \mathrm{b}}$, José M. Loureiro a \\ Rui A.R. Boaventura ${ }^{\text {a }}$ \\ a Laboratory of Separation and Reaction Engineering (LSRE), Associate Laboratory LSRE/LCM, Departamento de Engenharia Química, Faculdade de \\ Engenharia, Universidade do Porto, Rua do Dr. Roberto Frias, 4200-465 Porto, Portugal \\ ${ }^{\mathrm{b}}$ Department of Chemical and Biological Technology, Superior School of Technology, Polytechnic Institute of Bragança, Campus de Santa Apolónia, \\ 5301-857 Bragança, Portugal
}

\section{A R T I C L E I N F O}

\section{Article history:}

Received 27 June 2014

Received in revised form

20 October 2014

Accepted 27 October 2014

Available online 1 November 2014

\section{Keywords:}

Fish canning wastewater

Wastewater reuse

Reverse osmosis

UV disinfection

Coagulation-flocculation

Biological treatment

\begin{abstract}
A B S T R A C T
The valorization of wastewaters from the fish canning industry is of great concern, not only because of the high quantities generated, but also economic and environmental benefits may result from a proper treatment approach of the waste generated while reducing costs related to wastewater discharge.

A limiting factor for reuse and recycling treated fish canning wastewater into an industrial plant and also for other uses is the high salt content, which persists even after conventional treatment. So, the reuse of fish canning industrial wastewater was assessed by combining conventional treatments, such as sedimentation, chemical coagulation-flocculation and aerobic biological degradation (activated sludge process) followed by a polishing step by reverse osmosis (RO) and ultraviolet (UV) disinfection.

In this investigation all these processes were optimized in order to remove essentially the effluent suspended particles (primary treatment), the organic matter content in the biological aerated reactor (secondary treatment) and, finally, the remaining salts and microorganisms (tertiary treatment).

The overall removal efficiencies obtained were: $99.9 \%$ for dissolved organic carbon (DOC), $99.8 \%$ for oil and grease $(O \& G), 98.4 \%$ for total suspended solids (TSS), above $96 \%$ for anions and cations and $100 \%$ for heterotrophic bacteria expressed as colony-forming units (CFU). The final clarified effluent was found to have the quality requirements to be recycled or reused in the industrial plant, allowing the reduction of the effluent to be discharged, the water use and the costs of tap water for industrial use.

As regards the energy and chemicals costs, to obtain a treated effluent to be reused in the process costs $0.85 € / \mathrm{m}^{3}$. This value can be reduced by about $60 \%$ if the goal is only to meet the legislated standards for the effluent discharge into water bodies. Tap water for the industrial plant costs about $2.1 € / \mathrm{m}^{3}$.
\end{abstract}

() 2014 Elsevier Ltd. All rights reserved.

\section{Introduction}

Water consumption in fish processing industry and the production of high strength wastewaters are of great concern worldwide (Chowdhury et al., 2010). In fact, in this type of industries a huge amount of water is used throughout all steps, including cleaning, cooking, cooling, sanitization and floor washing. Fish canning wastewaters are known to contain organic contaminants in soluble, colloidal and particulate form (Chowdhury et al., 2010). The biodegradable organic matter is mainly in the form of proteins and lipids. The concentration and volume of wastewater from fish

\footnotetext{
* Corresponding author. Tel.: +351 22508 2263; fax: +351 225081674 .

E-mail address: raquel.cristovao@fe.up.pt (R.O. Cristóvão).
}

processing varies widely, depending on the fish to be processed, the additives used (e.g. brine, oil, tomato sauce), the unit processes involved and the source of the water (Palenzuela, 1999), among other factors. There is a need, for both economic and environmental sustainability reasons, to consider the wastewater treatment in order to obtain water with the quality requirements established by the European Directive 98/83/EC (Table 1), which allows its reuse into the industrial process.

Fish processing wastewaters are generally treated using physical-chemical methods (Fahim et al., 2001), biological methods (Palenzuela, 1999), or a combination of both. In integrated treatment systems, sedimentation, dissolved air flotation and $\mathrm{pH}$ adjustment are usually employed as primary treatment steps (Zufía and Aurrekoetxea, 2002) and the biological processes (aerobic and anaerobic) are known to be the more appropriate for organics 
Table 1

Parametric values established by the European Directive 98/83/EC for water intended for human consumption or used in food-processing industries.

\begin{tabular}{|c|c|c|}
\hline Parameter & Unit & Parametric value \\
\hline Aluminum & $\mathrm{Mg} \mathrm{Al} / \mathrm{L}$ & 200 \\
\hline Ammonium & $\mathrm{Mg} \mathrm{NH}_{4} / \mathrm{L}$ & 0.50 \\
\hline Calcium & $\mathrm{mgzCa} / \mathrm{L}$ & - \\
\hline Chlorides & $\mathrm{Mg} \mathrm{Cl} / \mathrm{L}$ & 250 \\
\hline $\begin{array}{l}\text { Clostridium perfringens } \\
\text { (including spores) }\end{array}$ & $\mathrm{N} / 100 \mathrm{~mL}$ & 0 \\
\hline Color & $\mathrm{Mg} \mathrm{PtCo} / \mathrm{L}$ & 20 \\
\hline Conductivity & $\mu \mathrm{S} / \mathrm{cm}, 20^{\circ} \mathrm{C}$ & 2500 \\
\hline Total hardness & $\mathrm{Mg} \mathrm{CaCO}_{3} / \mathrm{L}$ & - \\
\hline $\mathrm{pH}$ & $\mathrm{pH}$ units & $\geq 6.5$ e $\leq 9$ \\
\hline Iron & $\mathrm{Mg} \mathrm{Fe} / \mathrm{L}$ & $200-$ \\
\hline Magnesium & $\mathrm{Mg} \mathrm{Mg} / \mathrm{L}$ & - \\
\hline Manganese & $\mathrm{Mg} \mathrm{Mn/L}$ & 50 \\
\hline Microcystin - full LR & $\mu \mathrm{g} / \mathrm{L}$ & 1 \\
\hline Smell, $25{ }^{\circ} \mathrm{C}$ & Dilution factor & 3 \\
\hline Oxidability & $\mathrm{Mg} \mathrm{O}_{2} / \mathrm{L}$ & 5 \\
\hline Sulphates & $\mathrm{Mg} \mathrm{SO}_{4} / \mathrm{L}$ & 250 \\
\hline Sodium & $\mathrm{Mg} \mathrm{Na} / \mathrm{L}$ & 200 \\
\hline Flavor, $25^{\circ} \mathrm{C}$ & Dilution factor & 3 \\
\hline Colony-forming units & $\mathrm{N} / \mathrm{mL}, 22{ }^{\circ} \mathrm{C}$ & $\begin{array}{l}\text { Without abnormal } \\
\text { change }\end{array}$ \\
\hline Coliform bacteria & $\mathrm{N} / 100 \mathrm{~mL}$ & 0 \\
\hline Total organic carbon (TOC) & $\mathrm{mg} / \mathrm{L} \mathrm{C}$ & $\begin{array}{l}\text { without abnormal } \\
\text { change }\end{array}$ \\
\hline Turbidity & UNT & 4 \\
\hline$\alpha$-total & $\mathrm{Bq} / \mathrm{L}$ & 0.5 \\
\hline$\beta$-total & $\mathrm{Bq} / \mathrm{L}$ & 1 \\
\hline Tritium & $\mathrm{Bq} / \mathrm{L}$ & 100 \\
\hline Total indicative dose & mSv/year & 0.10 \\
\hline Residual desinfectant & $\mathrm{mg} / \mathrm{L}$ & - \\
\hline
\end{tabular}

removal (Alexandre et al., 2011; Chowdhury et al., 2010). However, fish canning wastewaters also have high salinity. The elimination of salts is usually expensive and, on the other hand, the high salinity and the seasonal variation of the effluent characteristics make difficult to remove the organic matter by a biological process (Zufía and Aurrekoetxea, 2002). Nevertheless, for water reuse, a polishing step to remove the effluent salinity is necessary. Recent studies revealed that membrane separations may help in solving the problem of attaining a quality of water that allows being recycled back to the process (Mavrov and Bélières, 2000). Membrane separation allows the removal of contaminants, the recovery of dissolved or suspended high added value constituents (proteins, pigments, enzymes, etc.) (Martin et al., 1995) and even the water reuse for certain applications (Rautenbach and Linn, 1996). Kuca and Szaniawska (2009) studied the application of microfiltration using ceramic membranes for treatment of salted aqueous effluents from fish processing and Pérez-Gálvez et al. (2011) investigated the performance of three ceramic membranes in the treatment of the press liquor resulting from the compaction of sardine by-products. However, reverse osmosis is based on a lower pore size (around 0.001 micron), which allows the retention of smaller particles, including most ions present in the water. Reverse osmosis has been shown to be able to separate the salt content out of wastewater, retaining small ions such as $\mathrm{Na}^{+}$or $\mathrm{Cl}^{-}$(Rautenbach and Mellis, 1995).

Although conventional treatment processes remove up to 95-99\% of some microorganisms, the presence of pathogens render the water inappropriate for direct reuse. The safe reuse of water therefore depends on wastewater disinfection (Gómez et al., 2006). Requirements for wastewater reuse are based principally on biological quality considerations. However, due to wide fluctuations in industrial effluent quality, this becomes more challenging. Chlorination is the most widely used method to inactivate pathogenic microorganisms in water and wastewater. However, questions have been raised regarding the formation of disinfection by-products (DBPs), known as carcinogens (Liberti et al., 2003), the erosion of water pipes and unsafe operation (Guo et al., 2011). In recent years, UV light has been increasingly used as a disinfectant, to inactivate bacteria without the formation of toxic by-products (Hijnen et al., 2006). In addition, the photoreactor design and lamp technology have improved considerably (Cassano et al., 1995). These facts led to the recognition by US Environmental Protection Agency (USEPA) that UV disinfection is the best current disinfection technology (Hijnen et al., 2006). UV light, emitted by mercury arclamps (low or medium pressure), is effective against a variety of pathogens including viruses, bacteria and protozoan cysts (Hallmich and Gehr, 2010). Essentially, the inactivating effects of UV rays are due to DNA changes (e.g., strand breaks, formation of thymine dimers) that result in inhibition of replication and, in case of lethal doses, in a loss of reproducibility. A disadvantage of this method is the possible reactivation of UV damaged microorganisms. However, reactivation decreases significantly when the water is exposed to visible light, simultaneously or prior to UV irradiation (Guo et al., 2009; Hallmich and Gehr, 2010).

This work intends to develop a real, effective and workable solution that avoids and/or reduces the rejection of wastewaters from the fish canning industry, managing them in the most appropriate way to obtain a product with higher added value (water) which can be reused. This objective will be achieved through the optimization of a series of various treatment steps envisaging the wastewater reuse in the industrial process, while reducing the discharge of effluent, limiting the water use and saving money. To our knowledge this is the first investigation of a combined treatment of fish canning industrial wastewaters for water reuse.

\section{Fish canning process}

The fish canning production process begins with the reception of raw materials (fish, sauces and packaging materials). In the fishing boats, the fish is kept in water tanks. At the factory, the water drains out and the fish is weighed and stored again in salted water. The main waste stream resulting from this operation is the water used in the fish transport, along with water used for preservation in the boats. The wastewater from this stage contains blood, fish, rocks and sand from the fishing boats tanks.

Then the fish is placed in brine, a process that requires water and produces an effluent especially rich in salt, blood and scales. Then unwanted fish parts are removed, particularly head and viscera, to which is also necessary the use of water. From this process results an effluent mainly contaminated with salt, blood and fish waste that cannot be used as food. In the fish washing process water is used in abundance. From this operation results a wastewater containing mainly blood, oil, flakes, salt and fish tissues.

The following process corresponds to the cooking and subsequent cooling of the fish. The fish cooking is done through direct contact with steam. After cooking, the water produced is drained and the fish is cooled by water spraying. There are two sources for the wastewater generated in this process: one originated from the cooking, which has a very high concentration of organic material and fats and other from washing and cooling (usually seawater) that has low organic load, but high salinity. Hence, the fish goes to canning, sauces addition, spiking and cans washing processes. This final wash leads also to an effluent that contains, essentially, fish fat. Finally, the cans are sterilized with steam and cooled with water, which also results in a wastewater. In addition to all these wastewaters produced, liquid spills occur due to shipping, handling, canning and cleaning of equipment, involving waste of raw materials. 
The water used in the various steps of the process can be replaced by reused water from the treatment of the wastewaters generated.

\section{Materials and methods}

\subsection{Wastewater characterization}

A sampling program was carried out in a selected fish canning company with a production capacity of 100,000 cans/day, located at Póvoa de Varzim, in northern Portugal. Several samples of $100 \mathrm{~L}$ of wastewater were collected weekly during 3 months and characterized after a preliminary screening stage. Standard Methods for the Examination of Water and Wastewater (APHA, 2005) were adopted for the measurement of total suspended solids (TSS), volatile suspended solids (VSS), dissolved organic carbon (DOC), chemical oxygen demand (COD), biological oxygen demand $\left(\mathrm{BOD}_{5}\right)$, oil and grease $(\mathrm{O} \& \mathrm{G})$, total phosphorus $\left(\mathrm{P}_{\text {total }}\right)$, total soluble nitrogen ( $\left.\mathrm{N}_{\text {total soluble }}\right)$, ammoniacal nitrogen $\left(\mathrm{N}_{\text {ammoniacal }}\right)$ and several anions and cations. A Shimadzu 5000A Total Organic Carbon analyzer was employed for DOC measurements. The reported values represent the average of at least two measurements; in most cases each sample was injected three times, validation being performed by the apparatus only if the coefficient of variation (CV) was smaller than $2 \%$.

The $\mathrm{pH}$ was measured using a selective electrode (Hanna Instruments HI 1230) and a pH meter (Hanna instruments HI 8424) and the conductivity at $20^{\circ} \mathrm{C}$ was determined using a conductivity probe (WTW TetraCon 325) and a conductivity meter (WTW LF538).

Anions were measured by ion chromatography (Dionex ICS2100) using a Dionex Ionpac (column AS 11-HC $4 \times 250 \mathrm{~mm}$; suppressor ASRS $3004 \mathrm{~mm}$ ). Cations were analyzed also by ion chromatography (Dionex DX-120), using a Dionex Ionpac (column CS12A $4 \times 250 \mathrm{~mm}$; suppressor CSRS $3004 \mathrm{~mm}$ ). Isocratic elution was achieved with $\mathrm{NaOH} 30 \mathrm{mM} /$ methanesulfonic acid $20 \mathrm{mM}$ at a flow rate of $1.5 / 1.0 \mathrm{~mL} / \mathrm{min}$ for anions/cations analysis, respectively.

\subsection{Wastewater treatment sequence}

A sequential treatment for fish canning wastewaters was investigated for water reuse (Fig. 1). This sequence consists of sedimentation/flotation (gravity separation) for settleable solids, floatable oils and grease removal, coagulation-flocculation using $\mathrm{FeCl}_{3}$ as coagulant for additional removal of oil and grease and nonsettleable solids, aerobic biological treatment (conventional activated sludge process) for soluble organic matter degradation, reverse osmosis (low pressure composite membrane) for salts removal and, finally, UV disinfection (low pressure mercury lamp) for microorganisms' inactivation.

\subsubsection{Sedimentation/flotation}

The first stage of the wastewater treatment process was sedimentation/flotation. The removal of suspended particles by sedimentation or flotation depends upon the size and specific gravity of the particles. Suspended solids may remain in suspension if their specific gravity is similar to water while very dense particles settle down. So, the effluent was left in graduated cylinders $(42 \mathrm{~cm}$ height and $5.8 \mathrm{~cm}$ internal diameter) for $1.5 \mathrm{~h}$. The optimum sedimentation time was determined in previous sedimentation tests. The graduated cylinders are provided with a sampling port, $5 \mathrm{~cm}$ above the bottom, which allows taking samples directly from the middle layer (Fig. 2(a)). These samples were then analyzed for TSS, DOC and $\mathrm{O} \& \mathrm{G}$.

\subsubsection{Coagulation/flocculation}

The coagulation/flocculation process is used to remove colloidal particles and, whenever the natural settling of suspended material is not possible or is too slow, to provide effective clarification. The addition of coagulants causes the destabilization of the colloids,

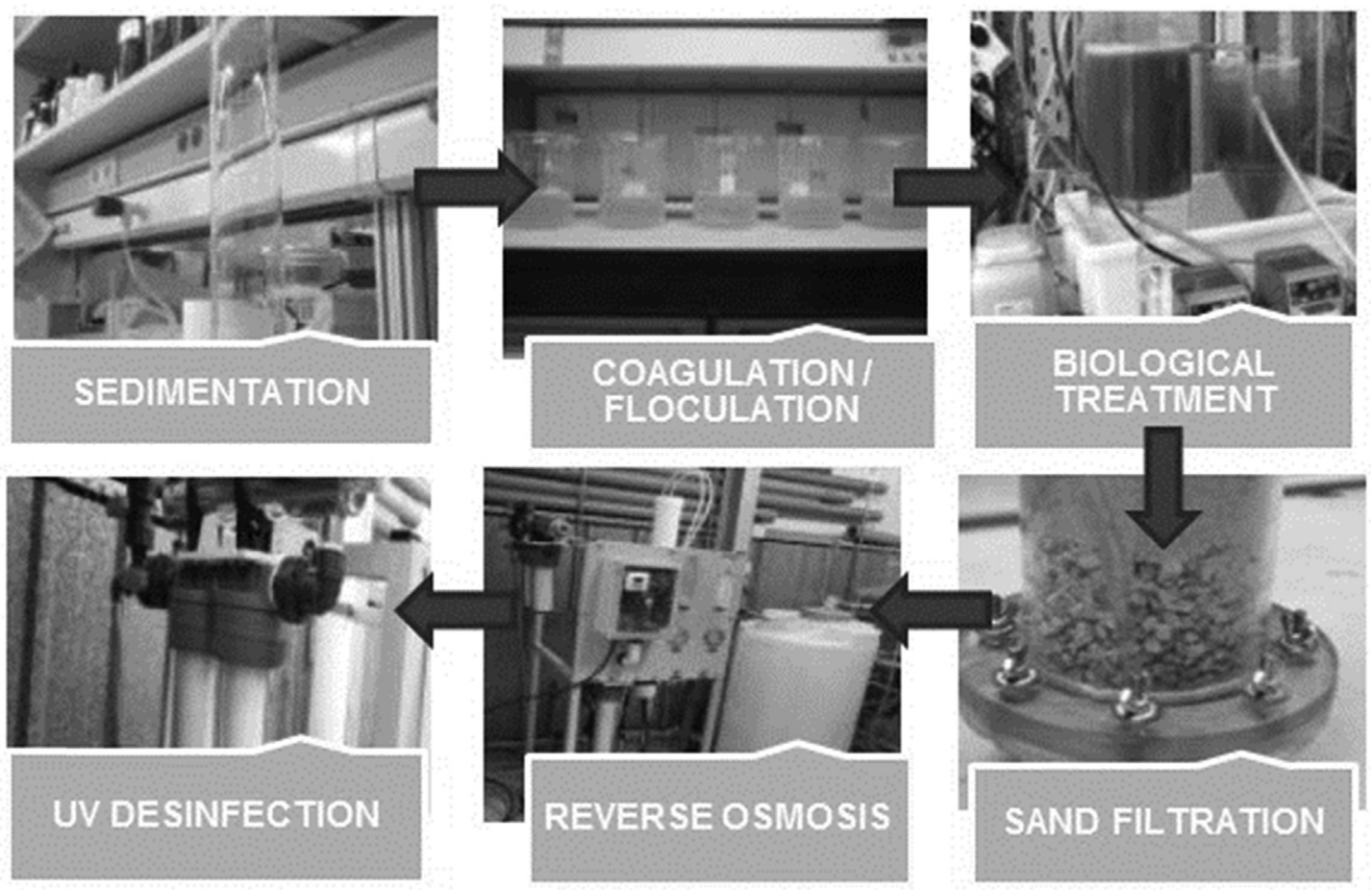

Fig. 1. Treatment sequence for fish canning wastewaters reuse. 


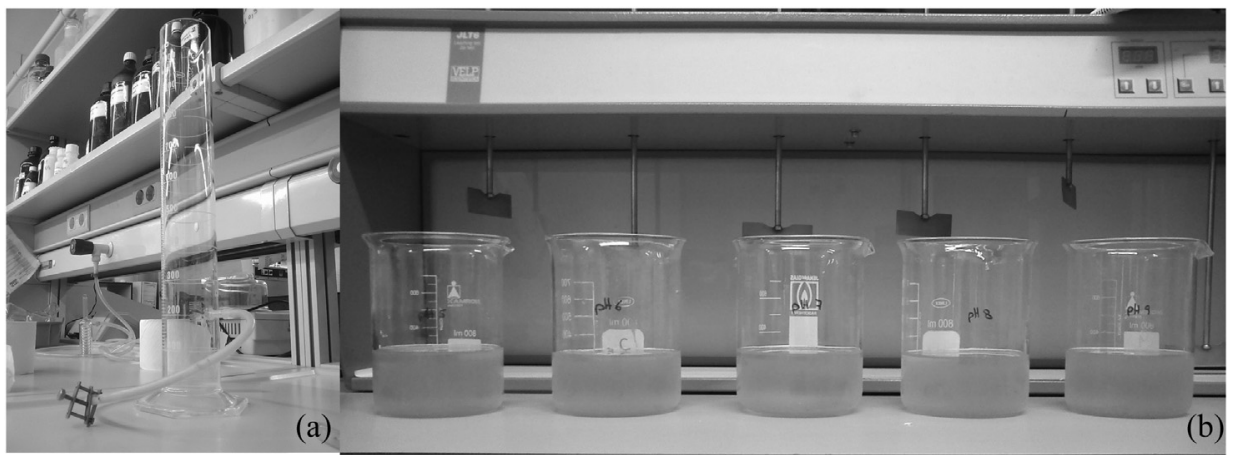

Fig. 2. (a) Sedimentation/flotation and (b) coagulation/flocculation treatment lab-scale plant for effluent primary treatment stage.

followed by particles collision and flocs formation. Flocs are separated from the water by sedimentation or flotation. The performance of a particular coagulant depends upon the quality of the wastewater. Different types of coagulants were selected and their performance was assessed by varying the dosages employed and the $\mathrm{pH}$ of the wastewater.

So, the clarified wastewater, from the sedimentation/flotation stage, was submitted to chemical coagulation/flocculation, using a standard jar test apparatus (Jar tester JLT6, VELP Scientifica) (Fig. 2(b)). The adequate coagulant dosage and $\mathrm{pH}$ were optimized by performing several jar-tests, using 7 coagulants (2 organic compounds (RIPOL 070 and RIPOL 1815) and 5 inorganic salts (aluminum sulfate $\left(\mathrm{Al}_{2}\left(\mathrm{SO}_{4}\right)_{3} \cdot 16 \mathrm{H}_{2} \mathrm{O}\right)$, ferric sulfate $\left(\mathrm{Fe}_{2}\left(\mathrm{SO}_{4}\right)_{3}\right)$, ferric chloride $\left(\mathrm{FeCl}_{3}\right)$, calcium chloride $\left(\mathrm{CaCl}_{2}\right)$ and polyaluminium chloride (PAX-18)), at 3 out of 5 different coagulant dosages (from 20 to $400 \mathrm{mg} / \mathrm{L}$ ). The $\mathrm{pH}$ was varied between 5 and 9 for each optimum coagulant dosage achieved. Each jar was filled with $500 \mathrm{~mL}$ of sample and the coagulant dose and $\mathrm{pH}$ value were adjusted to the intended values. The experimental procedure consisted of rapid mixing at $150 \mathrm{rpm}$ for $3 \mathrm{~min}$ and, after that, the wastewater was moderately stirred at $20 \mathrm{rpm}$ for $15 \mathrm{~min}$ to promote flocculation. Finally, a $1 \mathrm{~h}$ sedimentation stage allowed the flocs formed to settle.
The supernatants obtained were then characterized in terms of TSS and O\&G.

\subsubsection{Biological treatment}

The biological treatment was applied to the fish canning wastewater after sedimentation/flotation and coagulation/flocculation steps in order to evaluate the organic matter removal efficiency by activated sludge. A sample of suspended biomass from the aeration tank of a Municipal Wastewater Treatment Plant (Porto, Portugal) was used as inoculum. Aeration of the wastewater provides oxygen to aerobic microorganisms' metabolic process, causing the flocs formation - activated sludge - and allowing the reduction of the organic content of the wastewater. The flocs are separated from the treated effluent by sedimentation.

The experiments for this study were performed in a biological system that consists of a $110 \mathrm{~L}$ feed tank containing the wastewater to be treated, an aeration tank (internal diameter (ID) $=19 \mathrm{~cm}$, height $(\mathrm{H})=33 \mathrm{~cm}$, working volume $(\mathrm{V})=6 \mathrm{~L}$ ) equipped with air diffusers at the bottom to ensure the oxygen supply and the mixing of the whole reactor content (the air flow rate was about $6 \mathrm{~L} \mathrm{~min}^{-1}$ ), a secondary sedimentation tank (ID $=19 \mathrm{~cm}, H_{\text {cylinder }}=31 \mathrm{~cm}$, $H_{\text {conic }}=15 \mathrm{~cm}, \mathrm{~V}=6 \mathrm{~L}$ ) equipped with a sludge recirculation system

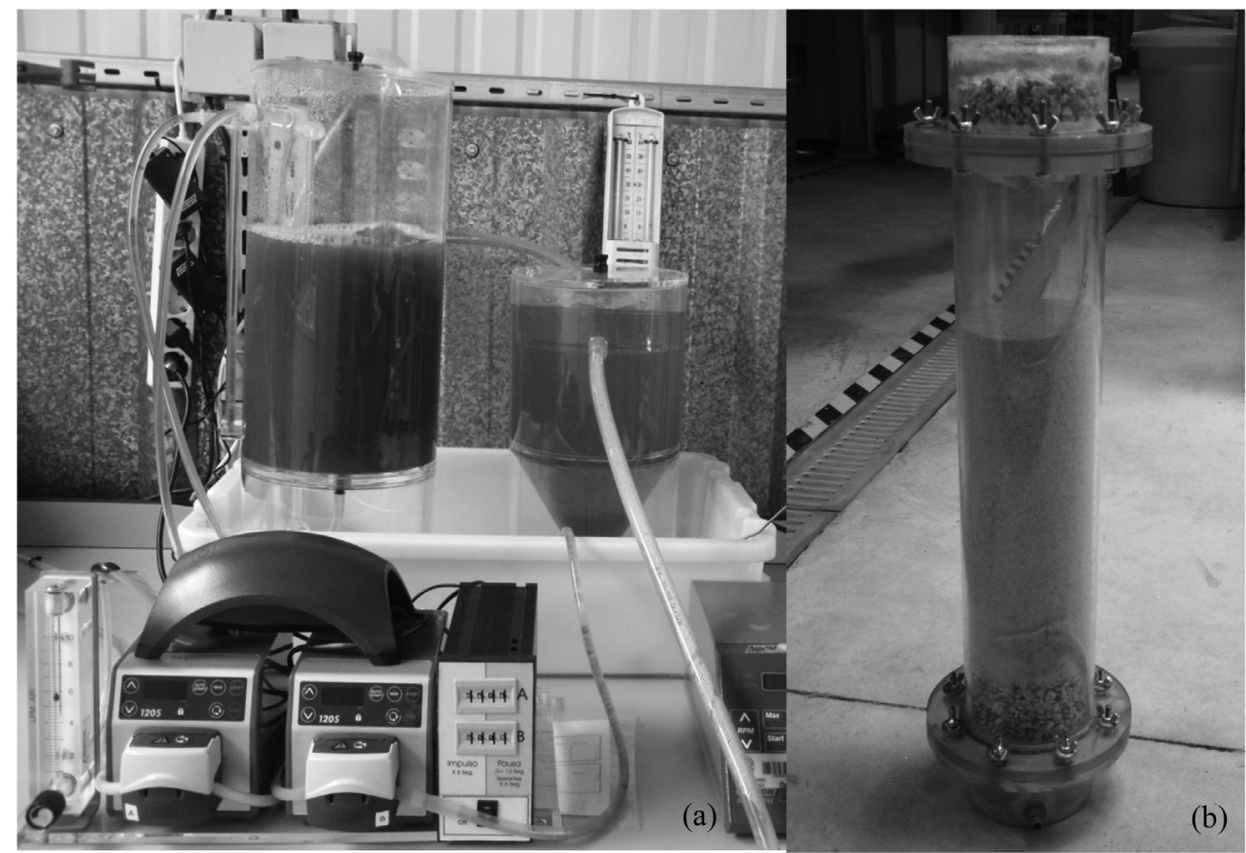

Fig. 3. Lab-scale plant for biological treatment with activated sludge (a) and sand filtration (b). 
and a storage tank for the final effluent (treated wastewater). There are also two peristaltic pumps operating at adjustable flow rate: one for reactor feeding and another for sludge recirculation (Fig. 3(a)).

Before conducting the biological treatment studies themselves, the acclimatization of the inoculum was carried out in batch mode during 20 days in order to obtain a biomass concentration in the reactor greater than $1500 \mathrm{mg} \mathrm{ssv} / \mathrm{L}$. Once reached this value, the operation was shifted to continuous mode. Temperature (T), $\mathrm{pH}$ and dissolved oxygen (DO) were approximately $\mathrm{T}=22 \pm 2{ }^{\circ} \mathrm{C}$, $\mathrm{pH}=7.5 \pm 0.5, \mathrm{DO}=2.0 \pm 0.5 \mathrm{mg} / \mathrm{L}$, respectively, throughout the experiments.

The reactor was operated at different hydraulic retention times (HRT): 5.0, 6.0 and $8.0 \mathrm{~h}$, and the DOC of the feeding stream was between 600 and $700 \mathrm{mg} / \mathrm{L}$, approximately. Influent and effluent samples were taken to measure DOC values.

\subsubsection{Filtration}

The sand filter allows the particles retention from the upstream treatments, as well as of the biomass from the secondary clarifier. The wastewater passes downstream through several sand layers of decreasing particle size, which allows for the retention of the impurities.

Paterniani and Conceição (2001) claim that sand filtration process has some advantages over other technologies, highlighting the non-chemicals usage, not requiring process control sophisticated equipment, besides being of simple construction. These advantages, together with the use of alternative materials and simple hand work, can reduce the initial costs of construction, operation and maintenance.

So, in order to remove residual suspended solids found in the secondary effluent that may interfere with the subsequent RO process, simultaneously reducing the concentration of organic matter and turbidity (Hamoda et al., 2004), the biologically treated effluent was passed through a rapid sand filter, before reverse osmosis and UV disinfection processes.

The filter used in the filtration stage was a gravity sand filter (50 cm height and 11.3 internal diameter) composed of a $40 \mathrm{~cm}$ layer of sand (density $2.6 \mathrm{~g} / \mathrm{cm}^{3}$ ) with diameter between 0.5 and $1 \mathrm{~mm}$. Two $5 \mathrm{~cm}$ gravel layers were placed on the top and on the bottom of the filter column to better distribute the water over the sand and to act as support medium, respectively (Fig. 3(b)). The filter was designed and operated to provide an average filtration rate of $2.4 \mathrm{~m}^{3} \mathrm{~m}^{-2} \mathrm{~d}^{-1}$. The efficiency of the sand filter was assessed in terms of TSS reduction.

\subsubsection{Reverse osmosis}

Reverse osmosis is a membrane separation process, under pressure, in order to produce very high quality water, by removing some suspended contaminants, and separating low molecular weight dissolved substances (ions and soluble organic and inorganic compounds), and microorganisms.

The effluent from the sand filter was stored in a 600 L-capacity feed tank and then pumped to the reverse osmosis system by a MEW pump QB-70, at a maximum flow rate of $7.7 \mathrm{~L} / \mathrm{min}$.

The reverse osmosis pilot consisted of an RO 250 Model from AQUAQUÍMICA, Lda. (Fig. 4), allowing a maximum permeate flow rate of $250 \mathrm{~L} / \mathrm{h}$ and a pressure between 7 and 15 bar. This system consists of one Thin Layer Composite (TLC) membrane $(5 \mu \mathrm{m}$, $40 \times 40$ inch), membrane housing of plastic reinforced with fiberglass (PRFG) and works at operating temperatures between 13 and $30{ }^{\circ} \mathrm{C}$. The installed pump is Efaflu/Lowara with a $2.2 \mathrm{~kW} / 400 \mathrm{~V}$ motor, minimum pressure inlet alarm and pump protection.

The reverse osmosis (RO) tests were carried out at permeate flow rates between 192 and $216 \mathrm{~L} / \mathrm{h}$ and concentrate flow rates

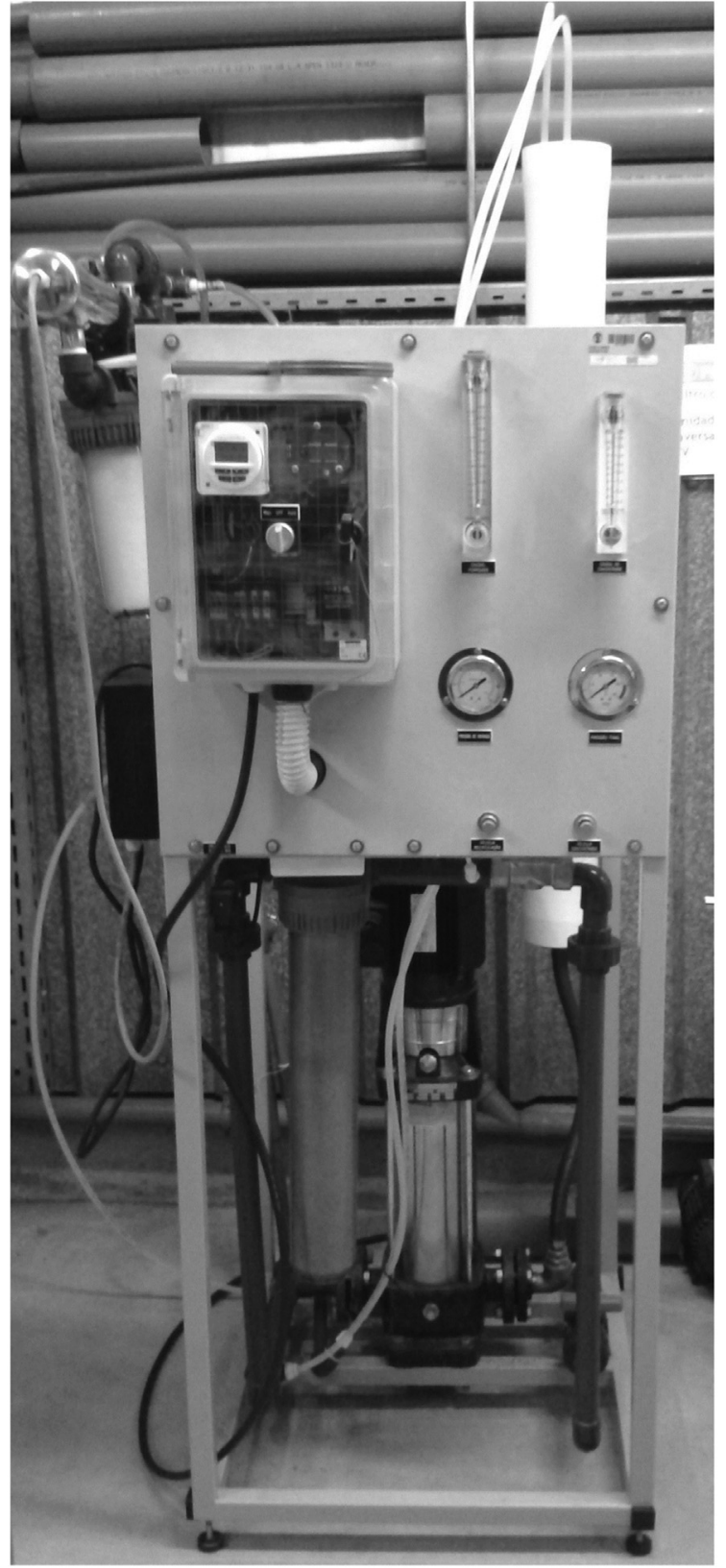

Fig. 4. Pilot plant for reverse osmosis studies.

between 60 and $270 \mathrm{~L} / \mathrm{h}$. The pressure was varied between 8.5 and 10.0 bar. Feed flow rate and operational pressure were adjusted by controlling valves of recirculation and concentrated streams and visualized in pressure gages and flow meters. The RO plant was operated at a recovery rate between 50 and $75 \%$ by adjusting the concentrate drain valve according to the permeate flow achieved.

The permeate is sent to the UV disinfection unit and the concentrate is discharged into the sewerage system. Before sending the permeate to the last treatment step some samples were collected from time to time to be analyzed for DOC, $\mathrm{N}_{\text {total soluble, }}$ conductivity, anions and cations.

The performance of RO membranes tends to decrease during operation as a biomass layer builds up on the membrane surface, which reduces the flux and permeate quality with a concurrent increase in differential pressure. Blockage of the membranes may lead to precipitation of salts on the membrane surface and in the 
feed inlets. A specific cleaning regime was developed to prevent the formation of the biomass layer, and consequently scaling and fouling, by passing chlorine solution $(1 \mathrm{mg} / \mathrm{L})$ throughout the system.

\subsubsection{UV disinfection}

The UV disinfection system uses UV light at sufficiently short wavelength to destroy the organism's genetic material (DNA and RNA), leaving them unable to perform vital cellular functions, as reproduction.

The UV disinfection equipment is composed of one $45 \mathrm{~W}$ lowpressure mercury discharge lamp, 1 and $5 \mu \mathrm{m}$ filters, an AISI 304 stainless steel chamber, an hour meter and electronic chokes. All components of the system are inside a steel AISI 316 L cylindrical reactor (Fig. 5). The equipment shall provide a minimum UV radiation dose of $25 \mathrm{~mW} \mathrm{~s}^{-} 1 \mathrm{~cm}^{-2}$ at the end of the lamp effective life.

The clarified effluent from the reverse osmosis system is fed to the UV disinfection system at a flow rate of $250 \mathrm{~L} / \mathrm{h}$. Then samples are collected after the disinfection and, finally, this effluent is evaluated as regards its suitability for water reuse. The samples before and after being subjected to UV disinfection were analyzed for the presence of microorganisms, by performing heterotrophic bacteria counts by scattering method with AGAR medium plates. The plates were incubated at 22 and $37{ }^{\circ} \mathrm{C}$, during 24 and $48 \mathrm{~h}$. Several dilutions were made for each sample.

\section{Results and discussion}

\subsection{Analysis of wastewaters from fish canning industries}

The quality of fish canning wastewaters varies according to the overall production of the fish canning industry. In order to obtain a representative set of data on effluent properties, several samples were collected at different times and analyzed. Their characteristics are presented in Table 2, where maximum and minimum values obtained for several samples are reported. The high $\mathrm{BOD}_{5}$ and $\mathrm{COD}$ values indicate a heavy contamination by organic matter. High contents of O\&G and salts are present, as indicated by the $\mathrm{Cl}^{-}$and $\mathrm{Na}^{+}$concentrations and conductivity (corresponding to salinity between 2.5 and $15 \mathrm{ppt}$ ).

\subsection{Primary treatment by sedimentation/flotation and coagulation/ flocculation}

The sedimentation/flotation and the coagulation/flocculation processes are the most important physico-chemical treatment steps in the primary treatment of some industrial wastewaters to reduce the suspended and colloidal particles responsible for turbidity. A screening device is also usually required; nevertheless, most fish canning industries already have implemented this kind of pre-treatment.

The results obtained show that sedimentation/flotation for $1.5 \mathrm{~h}$, was very effective in removing oil and grease and settleable solids. The mean values for TSS and O\&G removals were $48 \%$ and $75 \%$, respectively. Since this physical treatment does not promote a significant degradation of organic matter, DOC removal was only $4 \%$. These removal efficiencies are similar to values reported in the literature for other fish processing wastewaters. Muthukumaran and Baskaran (2013) concluded that the majority of the suspended solids that contribute to the organic load would be difficult to remove using a typical sedimentation system.

Following the sedimentation/flotation stage, a coagulation/ flocculation step was employed to remove the resistant suspended and colloidal materials still present in the wastewater. The most commonly used coagulants in wastewater treatment are inorganic

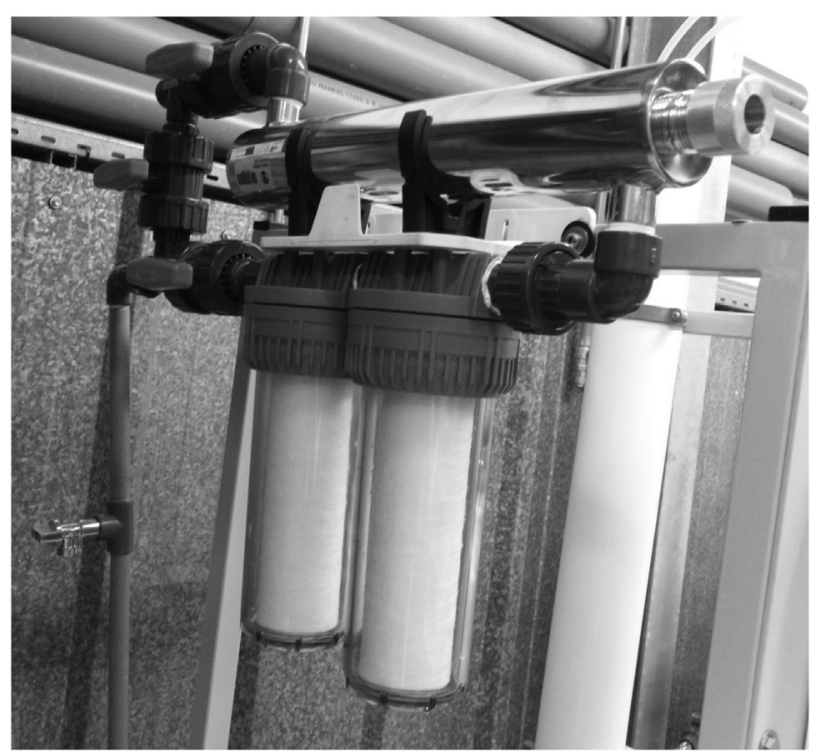

Fig. 5. UV disinfection system.

compounds (Amuda and Amoo, 2007; de Sena et al., 2008; Wang et al., 2007). So, aluminum sulfate, ferric sulfate, ferric chloride, calcium chloride and polyaluminium chloride were employed in initial experiments at coagulant doses of 100, 200 and $400 \mathrm{mg} / \mathrm{L}$. The results presented in Table 3 (a) show that there is not a single optimum coagulant for the chemical treatment of the wastewaters under study. The optimal coagulant and the respective optimal dosage depend on what it is wanted to remove in the moment. However, ferric chloride was found to be an effective coagulant in reducing both TSS (85.8\%) and O\&G (99.2\%) in the fish canning wastewater, at a dosage of $400 \mathrm{mg} / \mathrm{L}$. Regarding DOC, none of the studied coagulants achieved significant removals. Other works also showed that the coagulant to use depends on the intended purpose. Amuda and Alade (2006) used alum, ferric chloride and ferric

Table 2

Seasonal variation of fish canning wastewater characteristics.

\begin{tabular}{|c|c|c|c|}
\hline \multicolumn{2}{|c|}{ Parameter } & Min & Max \\
\hline \multicolumn{2}{|c|}{$\mathrm{pH}$} & 6.13 & 7.14 \\
\hline \multicolumn{2}{|c|}{ Conductivity $\left(20^{\circ} \mathrm{C}\right)\left(\mathrm{mS} \mathrm{cm}^{-1}\right)$} & 4.73 & 24.8 \\
\hline \multicolumn{2}{|c|}{ TSS $\left(\mathrm{mg} \cdot \mathrm{L}^{-1}\right)$} & 324 & 3150 \\
\hline \multicolumn{2}{|c|}{$\operatorname{VSS}\left(\mathrm{mg} \cdot \mathrm{L}^{-1}\right)$} & 315 & 2680 \\
\hline \multicolumn{2}{|c|}{$\mathrm{DOC}\left(\mathrm{mg} \mathrm{C} \cdot \mathrm{L}^{-1}\right)$} & 90 & 2342 \\
\hline \multicolumn{2}{|c|}{$\operatorname{COD}\left(\mathrm{mg} \mathrm{O}_{2} \cdot \mathrm{L}^{-1}\right)$} & 1147 & 8313 \\
\hline \multicolumn{2}{|c|}{$\mathrm{BOD}_{5}\left(\mathrm{mg} \mathrm{O}_{2} \cdot \mathrm{L}^{-1}\right)$} & 463 & 4569 \\
\hline \multicolumn{2}{|c|}{$\mathrm{P}_{\text {total }}\left(\mathrm{mg} \mathrm{P} \cdot \mathrm{L}^{-1}\right)$} & 13 & 47 \\
\hline \multicolumn{2}{|c|}{$\mathrm{N}_{\text {total soluble }}\left(\mathrm{mg} \mathrm{N} \cdot \mathrm{L}^{-1}\right)$} & 21 & 471 \\
\hline \multicolumn{2}{|c|}{$\mathrm{N}_{\mathrm{ammoniacal}}\left(\mathrm{mg} \mathrm{NH} \mathrm{NH}_{3} \cdot \mathrm{L}^{-1}\right)$} & 3 & 1059 \\
\hline \multicolumn{2}{|c|}{ Oil and grease $\left(\mathrm{mg} \cdot \mathrm{L}^{-1}\right)$} & 156 & 2808 \\
\hline \multirow[t]{7}{*}{ Anions } & $\mathrm{F}^{-}\left(\mathrm{mg} \cdot \mathrm{L}^{-1}\right)$ & 7 & 60 \\
\hline & $\mathrm{Cl}^{-}\left(\mathrm{mg} \cdot \mathrm{L}^{-1}\right)$ & 174 & 5047 \\
\hline & $\mathrm{NO}^{2-}\left(\mathrm{mgz} \cdot \mathrm{L}^{-1}\right)$ & 3 & 355 \\
\hline & $\mathrm{SO}_{4}^{2-}\left(\mathrm{mg} \cdot \mathrm{L}^{-1}\right)$ & $<0.01$ & 91 \\
\hline & $\mathrm{Br}^{-}\left(\mathrm{mg} \cdot \mathrm{L}^{-1}\right)$ & $<0.01$ & 214 \\
\hline & $\mathrm{NO}^{3-}\left(\mathrm{mg} \cdot \mathrm{L}^{-1}\right)$ & $<0.07$ & $<0.07$ \\
\hline & $\mathrm{PO}_{4}^{3-}\left(\mathrm{mg} \cdot \mathrm{L}^{-1}\right)$ & $<0.00$ & 9 \\
\hline \multirow[t]{6}{*}{ Cations } & $\mathrm{Li}^{+}\left(\mathrm{mg} \cdot \mathrm{L}^{-1}\right)$ & 0 & 1 \\
\hline & $\mathrm{Na}^{+}\left(\mathrm{mg} \cdot \mathrm{L}^{-1}\right)$ & 86 & 2120 \\
\hline & $\mathrm{NH}_{4}^{+}\left(\mathrm{mg} \cdot \mathrm{L}^{-1}\right)$ & 24 & 217 \\
\hline & $\mathrm{K}^{+}\left(\mathrm{mg} \cdot \mathrm{L}^{-1}\right)$ & 5 & 159 \\
\hline & $\mathrm{Mg}^{2+}\left(\mathrm{mg} \cdot \mathrm{L}^{-1}\right)$ & 7 & 40 \\
\hline & $\mathrm{Ca}^{2+}\left(\mathrm{mg} \cdot \mathrm{L}^{-1}\right)$ & 60 & 221 \\
\hline
\end{tabular}


Table 3

O\&G, TSS and DOC removal efficiencies of a fish canning wastewater at (a) different dosages of several coagulants and (b) at different pH values.

\begin{tabular}{|c|c|c|c|c|c|c|c|c|c|c|c|c|c|c|c|}
\hline \multirow[t]{3}{*}{ (a) Coagulant } & \multicolumn{5}{|c|}{ O\&G removal (\%) } & \multicolumn{5}{|c|}{ TSS removal (\%) } & \multicolumn{5}{|c|}{ DOC removal (\%) } \\
\hline & \multicolumn{5}{|c|}{ Coagulant dosage (mg/L) } & \multicolumn{5}{|c|}{ Coagulant dosage (mg/L) } & \multicolumn{5}{|c|}{ Coagulant dosage (mg/L) } \\
\hline & \multicolumn{2}{|c|}{100} & \multicolumn{2}{|l|}{200} & 400 & \multicolumn{2}{|c|}{100} & \multicolumn{2}{|l|}{200} & 400 & \multicolumn{2}{|c|}{100} & \multicolumn{2}{|l|}{200} & 400 \\
\hline $\mathrm{Al}_{2}\left(\mathrm{SO}_{4}\right)_{3} \cdot 16 \mathrm{H}_{2} \mathrm{O}$ & \multicolumn{2}{|c|}{98.8} & \multicolumn{2}{|l|}{99.4} & 99.0 & \multicolumn{2}{|c|}{66.5} & \multicolumn{2}{|l|}{66.5} & 76.4 & \multicolumn{2}{|c|}{20.7} & \multicolumn{2}{|l|}{15.2} & 26.9 \\
\hline $\mathrm{Fe}_{2}\left(\mathrm{SO}_{4}\right)_{3}$ & \multicolumn{2}{|c|}{99.4} & \multicolumn{2}{|l|}{99.5} & 99.5 & \multicolumn{2}{|c|}{56.7} & \multicolumn{2}{|l|}{0.0} & 0.0 & \multicolumn{2}{|c|}{29.8} & \multicolumn{2}{|l|}{32.1} & 33.7 \\
\hline $\mathrm{FeCl}_{3}$ & & & 99.2 & & 99.2 & & & 72.4 & & 85.8 & & & 19.3 & & 25.2 \\
\hline $\mathrm{CaCl}_{2}$ & & & 95.6 & & 94.7 & & & 31.1 & & 46.5 & & & 24.2 & & 26.4 \\
\hline PAX-18 & & & 99.5 & & 98.9 & & & 80.3 & & 68.5 & & & 26.6 & & 33.4 \\
\hline (b) Coagulant & $\mathrm{O} \& \mathrm{G}$ & hoval ( & & & & TSS & oval (\% & & & & DOC & hoval ( & & & \\
\hline & $\mathrm{pH}$ & & & & & $\mathrm{pH}$ & & & & & $\mathrm{pH}$ & & & & \\
\hline & 5 & 6 & 7 & 8 & 9 & 5 & 6 & 7 & 8 & 9 & 5 & 6 & 7 & 8 & 9 \\
\hline $\mathrm{Al}_{2}\left(\mathrm{SO}_{4}\right)_{3} \cdot 16 \mathrm{H}_{2} \mathrm{O}$ & 97.5 & 97.7 & 97.8 & 97.4 & 95.9 & 47.8 & 59.0 & 68.3 & 72.0 & 68.3 & 2.3 & 14.7 & 8.2 & 9.5 & 3.0 \\
\hline $\mathrm{Fe}_{2}\left(\mathrm{SO}_{4}\right)_{3}$ & 97.0 & 98.5 & 97.0 & 98.6 & 97.1 & 45.9 & 45.9 & 45.9 & 51.5 & 64.6 & 10.1 & 10.5 & 17.8 & 21.9 & 8.8 \\
\hline $\mathrm{FeCl}_{3}$ & 96.7 & 97.1 & 95.8 & 98.5 & 97.6 & 60.8 & 68.3 & 68.3 & 62.7 & 70.1 & 8.8 & 0.2 & 15.6 & 13.4 & 8.9 \\
\hline PAX-18 & 97.7 & 98.2 & 97.9 & 97.0 & 98.5 & 59.0 & 49.6 & 60.8 & 70.1 & 57.1 & 0.0 & 0.6 & 0.0 & 0.0 & 0.0 \\
\hline RIFLOC 1815 & 97.3 & - & 97.7 & - & 98.5 & 50.7 & - & 68.7 & - & 70.1 & 19.0 & - & 23.1 & - & 23.1 \\
\hline
\end{tabular}

sulfate for abattoir wastewater treatment by coagulation/flocculation and found that alum was more effective in the reduction of TSS, whereas ferric sulfate was more effective in the COD reduction. Braz et al. (2010) also studied winery wastewater treatment by coagulation/flocculation using four different coagulants concluding that the best turbidity removals were achieved with aluminum sulfate, while TSS higher removals were obtained with calcium hydroxide. The same authors also reported the slight ability of coagulation/ flocculation to remove COD from winery wastewaters.

Organic coagulants can also be used in coagulation/flocculation. So, two organic coagulants (RIPOL 070 and RIFLOC 1815) in the range 20-400 mg/L were also employed (Cristóvão et al., 2012). Nevertheless, the best results obtained with these coagulants (78.7\% of TSS and 99.2\% of O\&G with $150 \mathrm{mg} / \mathrm{L}$ RIFLOC 1815) were not better than those obtained with the inorganic coagulants.

Another parameter that may influence this type of treatment is the $\mathrm{pH}$. Therefore, in addition to the studies carried out at the raw wastewater $\mathrm{pH}$, tests on the influence of $\mathrm{pH}$ in the range from 5.0 to 9.0 were also performed, in the best conditions previously encountered. The obtained results (Table 3(b)) show that despite the high removals obtained at alkaline $\mathrm{pH}$, the best removals occurred in the tests carried out without wastewater $\mathrm{pH}$ adjustment. Similar results were achieved by Martín et al. (2011) in the coagulation/flocculation treatment of wastewater resulting from sauce manufacturing. Optimization showed similar results under all $\mathrm{pH}$ conditions. In this work, alkaline $\mathrm{pH}$ was selected as it permitted ease of operation and lower operational costs due to the elimination of $\mathrm{pH}$ adjustment.

The removals obtained using $400 \mathrm{mg} / \mathrm{L}$ of ferric chloride led to a wastewater with suitable characteristics to forward to a secondary biological process for organics removal.

\subsection{Secondary treatment by activated sludge}

The previous steps, sedimentation/flotation and coagulation/ flocculation, were not very effective in DOC removal, because

Table 4

DOC removals from a fish canning wastewater by activated sludge under different HRT.

\begin{tabular}{llll}
\hline HRT $(\mathrm{h})$ & $\mathrm{DOC}_{\text {feed }}(\mathrm{mg} / \mathrm{L})$ & $\mathrm{DOC}_{\text {out }}(\mathrm{mg} / \mathrm{L})$ & DOC removal $(\%)$ \\
\hline 5 & 696 & 183 & 73.7 \\
6 & 620 & 85 & 86.2 \\
8 & 594 & 25 & 95.8 \\
\hline
\end{tabular}

soluble organics contribute significantly to the overall organic matter content of the fish canning wastewater. Likewise, the pretreated wastewater requires removal of organic components by a biological treatment process. In this case an aerobic biological treatment by activated sludge was employed. The biological aerobic reactor operated at HRT of 5, 6 and 8 h. The obtained results are presented in Table 4 and indicate that the biological treatability of this type of wastewaters, under aerobic conditions, is very satisfactory, since low DOC values were achieved at the reactor outlet. The highest DOC removal efficiency (95.8\%) corresponds to the highest HRT, which means that, if necessary, higher hydraulic retention times could be used, but greater aeration tanks would be required. The biological treatment of fish processing wastewaters was also studied by other researchers. Riaño et al. (2011) studied the treatment of a fish processing wastewater in two photobioreactors inoculated with microalgae from a lagoon containing aerobically treated swine slurry and with sludge from a membrane submerged bioreactor treating winery wastewater. In such system approximately $70 \%$ of total chemical oxygen demand (COD) removal was reached. A new pilot scale hybrid biofilm-suspended biomass membrane bioreactor was used by Artiga et al. (2008) to treat wastewaters generated in a fish canning factory. A COD removal efficiency of $92 \%$ was achieved after adaptation of the sludge to the salinity. Comparing these organic matter removal values with that obtained in this work, it is possible to confirm the feasibility and the reliability of the treatment by activated sludge, since the removals obtained were even higher.

\subsection{Tertiary treatment by filtration, reverse osmosis and UV disinfection}

Due to the high chloride concentration and to the presence of microorganisms, a polishing process by reverse osmosis and UV disinfection is necessary in order to reuse fish canning wastewater.

The biological treatment by activated sludge significantly reduced the organic content of the wastewater, but suspended biomass still present after clarification may cause fouling of reverse osmosis (RO) membranes. Thus, to reduce the fouling of reverse osmosis membrane and to prolong its life, a tertiary filtration of the pretreated wastewater is required.

So, The biologically treated effluent was passed through a rapid sand filter, before being pumped to reverse osmosis and UV disinfection processes. TSS values before and after the sand filter were measured and an appreciable reduction of TSS was achieved (78\%). This removal efficiency lies within the values reported in the 
literature for rapid sand filtration (Hamoda et al., 2004; Metcalf et al., 1991).

The aim of this study was to obtain treated water with enough quality to be reused in the industrial plant. The limit of salt content in waters for human consumption, measured as conductivity at $20{ }^{\circ} \mathrm{C}$, is $2500 \mu \mathrm{S} / \mathrm{cm}$ (European Directive 98/83/EC). Since reverse osmosis is an appropriate technology to remove salts from effluents, several tests were conducted in the RO unit (Fig. 4), at permeate flow rates between 192 and $213 \mathrm{~L} / \mathrm{h}$, concentrate flow rates between 60 and $270 \mathrm{~L} / \mathrm{h}$ and pressures between 8.5 and 10.0 bar. Ten trials were performed taking into account these variations as described in Table 5. A complete water analysis was done on permeates from the RO membrane. The DOC, $\mathrm{N}_{\text {total soluble and }}$ conductivity removals obtained at different operating conditions are presented in Table 5. It seems that for a similar pressure, the greater the permeate flow rate and the lower the concentrate flow rate, the better performance is achieved. The DOC and the conductivity removals increase from 89.6 to $97.3 \%$ and from 98.4 to $99.1 \%$, respectively, when increasing the permeate flow rate from 192 to $216 \mathrm{~L} / \mathrm{h}$. The best DOC, $\mathrm{N}_{\text {total soluble and conductivity removals }}$ (97.3, 99.8 and $99.1 \%$, respectively) were achieved for the following conditions (test no. 10): permeate flow rate of $216 \mathrm{~L} / \mathrm{h}$, concentrate flow rate of $60 \mathrm{~L} / \mathrm{h}$ and pressure of 9.0 bar. Under the conditions of test no. 10, the permeate was also analyzed for cations and anions, and the following removals were obtained: $98.9 \%$ for sodium, $97.0 \%$ for ammonium, $99.2 \%$ for potassium, $99.0 \%$ for magnesium, $98.5 \%$ for calcium, above $96.0 \%$ for lithium, $99.2 \%$ for chloride, $97.1 \%$ for nitrite, $99.8 \%$ for sulfate, $96.3 \%$ for bromide and $99.2 \%$ for phosphate. The overall performance of RO led to negligible concentrations of DOC, $\mathrm{N}_{\text {total soluble, conductivity, anions and cations }}$ (estimated salinity of $0.03 \mathrm{ppt}$ ), as shown in Table 6. Similar results were obtained by other authors. Scholz et al. (2005) showed that a combined treatment of MBR and RO allowed for $90-100 \%$ reduction of COD, BOD and ammonia in a mixed tannery effluent. Salt content was reduced by $97.1 \%$. Jin et al. (2013) verified that the combination of biological and membrane processes, including reverse osmosis, applied to coking wastewater led to water suitable for industrial reuse. Reuse of tannery wastewater was investigated by Ranganathan and Kabadgi (2011) employing conventional treatment methods like neutralization, clari-flocculation and biological processes as pre-treatment before RO separation process. About $93-98 \%, 92-99 \%$ and $91-96 \%$ removal of TDS, sodium and chloride, respectively, were achieved in 5 different tanneries. A large amount (70-85\%) of water could be recovered and recycled.

Considering these results, it may be concluded that the present solution has substantial potential in the treatment of fish canning industrial wastewater for subsequent reuse as process water or for irrigation. However, it is also necessary to ensure that the microbiological quality meets the legislation for water reuse in food

Table 5

Operating conditions and results from the tests carried out by reverse osmosis.

\begin{tabular}{|c|c|c|c|c|c|c|}
\hline \multirow[t]{2}{*}{ Tests } & \multirow{2}{*}{$\begin{array}{l}\text { Permeate } \\
\text { flow rate }(L / h)\end{array}$} & \multirow{2}{*}{$\begin{array}{l}\text { Concentrated } \\
\text { flow rate }(\mathrm{L} / \mathrm{h})\end{array}$} & \multirow{2}{*}{$\begin{array}{l}\text { Pressure } \\
\text { (bar) }\end{array}$} & \multicolumn{3}{|c|}{ Removals (\%) } \\
\hline & & & & DOC & $\mathrm{N}_{\text {total soluble }}$ & Conductivity \\
\hline 1 & 192 & 270 & 8.5 & 93.9 & 95.2 & 98.7 \\
\hline 2 & 192 & 240 & 8.5 & 96.6 & 96.0 & 96.0 \\
\hline 3 & 192 & 204 & 9.0 & 89.6 & 95.0 & 98.4 \\
\hline 4 & 198 & 90 & 9.0 & 96.0 & 95.9 & 98.4 \\
\hline 5 & 198 & 120 & 9.3 & 96.9 & 96.1 & 98.4 \\
\hline 6 & 198 & 180 & 10.0 & 96.1 & 96.2 & 98.1 \\
\hline 7 & 198 & 225 & 9.0 & 90.1 & 99.8 & 95.7 \\
\hline 8 & 210 & 120 & 9.0 & 95.5 & 99.8 & 99.0 \\
\hline 9 & 210 & 240 & 8.5 & 93.9 & 99.8 & 99.0 \\
\hline 10 & 216 & 60 & 9.0 & 97.3 & 99.8 & 99.1 \\
\hline
\end{tabular}

Table 6

DOC, $\mathrm{N}_{\text {total soluble, cations and anions concentrations and }}$ conductivity values achieved after treatment by reverse osmosis.

\begin{tabular}{lc}
\hline Parameter & Value \\
\hline DOC $(\mathrm{mg} / \mathrm{L})$ & 1.3 \\
$\mathrm{~N}_{\text {total soluble }}(\mathrm{mg} / \mathrm{L})$ & 0.1 \\
Conductivity $(\mu \mathrm{S} / \mathrm{cm})$ & 50 \\
Lithium $(\mathrm{mg} / \mathrm{L})$ & $<0.03$ \\
Sodium $(\mathrm{mg} / \mathrm{L})$ & 8.0 \\
Ammonium $(\mathrm{mg} / \mathrm{L})$ & 0.6 \\
Potassium $(\mathrm{mg} / \mathrm{L})$ & 0.6 \\
Magnesium $(\mathrm{mg} / \mathrm{L})$ & 0.2 \\
Calcium $(\mathrm{mg} / \mathrm{L})$ & 1.5 \\
Chloride $(\mathrm{mg} / \mathrm{L})$ & 6.1 \\
Nitrite $(\mathrm{mg} / \mathrm{L})$ & 0.3 \\
Sulfate $(\mathrm{mg} / \mathrm{L})$ & 0.1 \\
Bromide $(\mathrm{mg} / \mathrm{L})$ & 0.1 \\
Nitrate $(\mathrm{mg} / \mathrm{L})$ & $<0.07$ \\
Phosphate $(\mathrm{mg} / \mathrm{L})$ & 0.1 \\
\hline
\end{tabular}

industry (European Directive 98/83/EC - Table 1), which requires the application of UV disinfection to the permeate of RO process.

So, when treating the effluent from RO, performed at the best conditions, by UV radiation (Fig. 5), a count of heterotrophic bacteria was carried out both before and after the disinfection process, in order to assess the treatment effectiveness for the intended purpose. After incubation at 22 and $37{ }^{\circ} \mathrm{C}$ for 24 and $48 \mathrm{~h}$, it was found that the samples prior to UV disinfection still have plenty of microorganisms: $140,000 \mathrm{CFU} / 100 \mathrm{~mL}$ at $22{ }^{\circ} \mathrm{C}$ and $10,000 \mathrm{CFU} /$ $100 \mathrm{~mL}$ at $37{ }^{\circ} \mathrm{C}$. However, when the count was performed after disinfection, it was found that UV radiation is really effective in the effluent disinfection, as $100 \%$ removal of the bacteria present in the feed stream was achieved.

UV disinfection has also proved to be effective as regards other types of effluents to be reused in the industrial process. Mavrov and Bélières (2000) studied the treatment of three low-contaminated process waters from the food industry by a combination of pretreatment, membrane filtration and UV disinfection, achieving a treated water with quality enough to be reused in accordance with company's needs. Poultry slaughterhouse wastewater reclamation was investigated by de Nardi et al. (2011), using a lab-scale treatment system consisting of biological degradation (sequencing bath reactor), dissolved air flotation and UV disinfection. The final effluent met the quality standards of the legislation for both potable water and effluents to be discharged into receiving water bodies.

Taking into account the characteristics of the clarified effluent after the overall treatment proposed (Table 6) and knowing that UV disinfection is $100 \%$ effective, one can conclude that the treated water meets the values established for water intended for human consumption (European Directive 98/83/CE). The water reuse in the manufacturing process or, alternatively, for washing floors, irrigation, etc. is also possible.

The accumulated removal efficiencies in the different sequential treatment stages are presented in Fig. 6. Removals of 99.9\% for DOC, $99.8 \%$ for O\&G, $98.4 \%$ for TSS, $99.1 \%$ for conductivity, above $96 \%$ for anions and cations and 100\% for heterotrophic bacteria (CFU) were attained at the end of the proposed treatment sequence.

\subsection{Energy and chemicals costs}

Data on energy and chemicals costs to operate the wastewater treatment process at a flow rate of $10 \mathrm{~m}^{3}$ per day (working time $8 \mathrm{~h} \mathrm{day}^{-1}$ ) are summarized in this section. Operating costs regarding salaries, maintenance and others were not considered as they are less significant. 


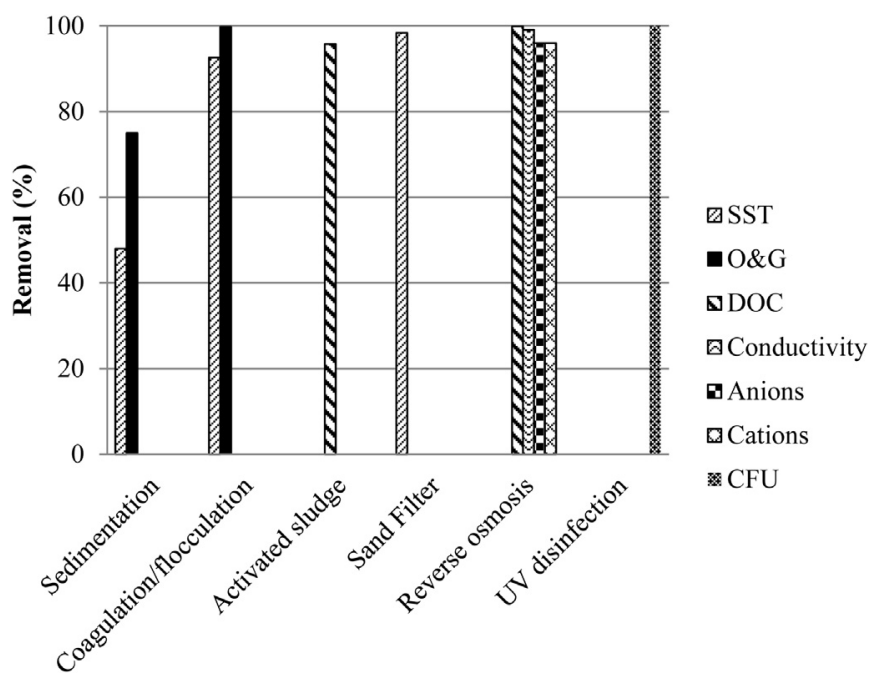

Fig. 6. Accumulated removal efficiencies of the different sequential stages of the fish canning wastewater treatment.

The first process comprises a flotation unit, $5 \mathrm{~m}^{3} / \mathrm{h}$ maximum flow capacity, $2.7 \mathrm{~kW}$ electric power (including energy consumption for surface scraper). So, the energy consumption is $5.4 \mathrm{kWh}$ per day.

Coagulation/flocculation unit comprises two steps: rapid mixing in a tank of $200 \mathrm{~L}$ during 5 min provided by an electrical agitator (shaft, coupling and four-bladed propeller at $45^{\circ}$, in stainless steel), a 3-phase current motor $230 / 400 \mathrm{~V}$, nominal power of $0.55 \mathrm{~kW}$ and nominal speed $106 \mathrm{rpm}$ (2.31 kWh per day); slow mixing at $32 \mathrm{rpm}$ in a $1000 \mathrm{~L}$ tank during $30 \mathrm{~min}$ also using an electrical agitator (shaft, coupling and propeller type 2R, in stainless steel), a 3-phase current motor 230/400 V with nominal power of $0.37 \mathrm{~kW}$ (energy consumption of $4.16 \mathrm{kWh} / \mathrm{d}$ ). In this process the optimum results were obtained with a $\mathrm{FeCl}_{3}$ dosage of $400 \mathrm{mg} / \mathrm{L}$, which corresponds to a daily consumption of $4 \mathrm{~kg}$. At a local supplier the cost of this chemical is about $290 €$ per tonne.

One of the main stages in the treatment plant is the activated sludge process. The mixture and aeration in the biological reactor (total volume of $10 \mathrm{~m}^{3}$ ) is achieved by a submersible aerator $(0.55 \mathrm{~kW})$ operating $10 \mathrm{~h}$ a day and, in a $5 \mathrm{~m}^{3}$ secondary clarifier ( $4 \mathrm{~h}$ detention time), a pump is installed for sludge recirculation (nominal power of $1.4 \mathrm{~kW}, 2 \mathrm{~h}$ per day). This contributes to a daily energy consumption of $8.3 \mathrm{kWh}$.

Before RO the residual suspended solids are removed in a pressurized multimedia filter unit equipped with an automatic valve: flow rate of $1400 \mathrm{~L} / \mathrm{h}$ (at maximum filtration velocity $15 \mathrm{~m} /$ h), $0.09 \mathrm{~m}^{2}$ filtration area and working pressure 4-6 bar. According to the manufacturer this requires a $3000 \mathrm{~L} / \mathrm{h}$ backwash flow (1.5-2.0 times the flow rate). So, a feeding/recirculating pump of $0.75 \mathrm{~kW}$ nominal power is needed to ensure $Q_{\max }=3 \mathrm{~m}^{3} / \mathrm{h}$ at $H_{\max }=3$ m.c.a. during a 20 min backwash daily period.

A reverse osmosis plant designed for a maximum flow rate of $250 \mathrm{~L} / \mathrm{h}$ (permeate flow rate equal to $75 \%$ of the inlet flow), including three RO membranes $40 \times 40(1016 \times 180 \times 180 \mathrm{~mm})$ and a multistage pump of $2.2 \mathrm{~kW} / 400 \mathrm{~V}$ motor can achieve the defined goals working $15 \mathrm{~h}$ a day.

Finally, the permeate ( $7500 \mathrm{~L} /$ day) was subjected to ultraviolet radiation in a cylindrical stainless steel reactor to promote its disinfection, using a $23 \mathrm{~W}$ low-pressure lamp operating continuously.

Table 7 summarizes the energy and the amount of coagulant $\left(\mathrm{FeCl}_{3}\right)$ consumed in each stage of the wastewater treatment
Table 7

Operating costs for the wastewater treatment process on a basis of $10 \mathrm{~m}^{3}$ per day (working time $8 \mathrm{~h} \mathrm{day}^{-1}$ ).

\begin{tabular}{llccc}
\hline Process unit & $\begin{array}{l}\text { Nominal } \\
\text { power (kW) }\end{array}$ & $\begin{array}{l}\text { Operation } \\
\text { time (hour) }\end{array}$ & $\begin{array}{l}\text { Energy } \\
\text { consumption } \\
(\mathrm{kWh} / \text { day })\end{array}$ & $\begin{array}{l}\text { Cost } \\
(€)\end{array}$ \\
\hline $\begin{array}{l}\text { Flotation } \\
\text { Coagulation/Flocculation }\end{array}$ & 2.7 & 2.0 & 5.40 & 0.76 \\
$\quad$ Coagulant $\left(\mathrm{FeCl}_{3}\right)^{\mathrm{a}}$ & & & & 1.16 \\
$\quad$ Rapid mixing & 0.55 & 4.2 & 2.31 & 0.33 \\
$\quad$ Slow mixing & 0.37 & 5.0 & 1.85 & 0.26 \\
$\begin{array}{l}\text { Activated Sludge } \\
\text { Mixture + Aeration }\end{array}$ & 0.55 & 10 & & 0.78 \\
$\quad$ Recirculation pump & 1.4 & 2.0 & 2.8 & 0.40 \\
Filtration & 0.75 & 0.5 & 0.23 & 0.03 \\
Reverse osmosis & 2.2 & 15 & 33 & 4.70 \\
UV disinfection & 0.023 & 24 & 0.55 & 0.08 \\
Total & & & & 8.50 \\
\hline
\end{tabular}

a Optimum dosage $=400 \mathrm{mg} / \mathrm{L}$ (amount $4 \mathrm{~kg} /$ day; cost $290 € /$ tonne).

process, as well as the total cost associated. The value obtained considers the unit costs of energy and ferric chloride, $0.1416 € / \mathrm{kWh}$ and $290 € /$ tonne, respectively. On this basis, the unit treatment cost to obtain a treated effluent suitable for reuse in the process is $0.85 €$ per cubic meter. As shown in Table 7, we can reduce costs by about $60 \%$ if the goal is only to treat the wastewater to meet the legislated discharge limits, i.e., if the tertiary treatment is excluded. Taking into account that the tap water cost for the manufacturing process, including taxes, is approximately $2.1 €$ per cubic meter, it is possible to conclude that even considering personnel, maintenance and produced sludge treatment/disposal costs, the wastewater reuse, after treatment, will be a benefit to the fish canning industry in study.

\section{Conclusions}

The fish canning industry wastewater treatment was investigated in order to obtain water with quality requirements to reuse in the industrial process.

The proposed sequential system, combining sedimentation/ flotation, coagulation/flocculation, aerobic biological degradation by activated sludge, filtration, reverse osmosis and UV disinfection, proved to be very effective. Removals of $48 \%$ for TSS and $75 \%$ for O\&G were observed in the sedimentation stage. For coagulation/ flocculation, ferric chloride showed to be the better coagulant at a dosage of $400 \mathrm{mg} / \mathrm{L}$ and raw wastewater $\mathrm{pH}$. O\&G and TSS removals attained 99.2 and $85.8 \%$, respectively. DOC was reduced by $95.8 \%$ in the biological process by activated sludge for HRT $=8 \mathrm{~h}$. In the tertiary treatment, the rapid sand filtration retained $78 \%$ of TSS whereas reverse osmosis removed $97.3 \%$ of DOC, $99.8 \%$ of $\mathrm{N}_{\text {total }}$ soluble, $99.1 \%$ of conductivity/salinity and above $96 \%$ of the analyzed ions. The removal of heterotrophic bacteria (CFU) by UV disinfection reached $100 \%$.

The overall removals attained by the treatment sequence under study were: $99.9 \%$ for DOC, $99.8 \%$ for O\&G, 98.4 for TSS, $99.1 \%$ for conductivity/salinity, above $96 \%$ for the analyzed ions and $100 \%$ for heterotrophic bacteria, which led to achieve, as intended, water with quality requirements for reuse in the industrial unit.

The treatment cost is $0.85 €$ per cubic meter but it can be reduced by about $60 \%$ if the goal is only to treat the wastewater in order to meet the legislated discharge limits.

The implementation of this reuse process at large scale will bring both environmental and economic benefits, since it allows the reduction of the effluent to be discharged and the water consumption, thus decreasing the associated costs. 


\section{Acknowledgments}

This work is partially supported by project PEst-C/EQB/LA0020/ 2013, financed by FEDER through COMPETE - Programa Operacional Factores de Competitividade and by FCT - Fundação para a Ciência e a Tecnologia and by ValorPeixe - Valorização de Subprodutos e Águas Residuais da Indústria de Conservas de Peixe, project in co-promotion I\&DT QREN, $n^{\circ} 13634$, financed by FEDER through POFC - Programa Operacional Factores de Competitividade for which the authors are thankful. Raquel O. Cristóvão thanks FCT for the Post-doc Scholarship (SFRH/BPD/81564/2011).

\section{References}

Alexandre, V.M.F., Valente, A.M., Cammarota, M.C., Freire, D.M.G., 2011. Performance of anaerobic bioreactor treating fish-processing plant wastewater prehydrolyzed with a solid enzyme pool. Renew. Energy 36, 3439-3444.

Amuda, O.S., Alade, A., 2006. Coagulation/flocculation process in the treatment of abattoir wastewater. Desalination 196, 22-31.

Amuda, O.S., Amoo, I.A., 2007. Coagulation/flocculation process and sludge conditioning in beverage industrial wastewater treatment. J. Hazard. Mat. 141, $778-783$.

APHA, 2005. Standard Methods for the Examination of Water and Wastewater, twenty-first ed. (Washington, DC., United States of America).

Artiga, P., García-Toriello, G., Méndez, E., Garrido, J.M., 2008. Use of a hybrid membrane bioreactor for the treatment of saline wastewater from a fish canning factory. Desalination 221, 518-525.

Braz, R., Pirra, A., Lucas, M.S., Peres, J.A., 2010. Combination of long term aerated storage and chemical coagulation/flocculation to winery wastewater treatment. Desalination 263, 226-232.

Cassano, A.E., Martin, C.A., Brandi, R.J., Alfano, O.M., 1995. Photoreactor analysis and design: fundamentals and applications. Ind. Eng. Chem. Res. 34, 2155-2201.

Chowdhury, P., Viraraghavan, T., Srinivasan, A., 2010. Biological treatment processes for fish processing wastewater - a review. Biores. Technol. 101, 439-449.

Cristóvão, R.O., Botelho, C.M.S., Martins, R.J.E., Boaventura, R.A.R., 2012. Chemical and biological treatment of fish canning wastewaters. Int. J. Biosci. Biochem.. Bioinf. 2, 237-242.

de Nardi, I.R., Del Nery, V., Amorim, A.K.B., Santos, N.G., Chimenes, F., 2011. Performances of SBR, chemical-DAF and UV disinfection for poultry slaughterhouse wastewater reclamation. Desalination 269, 184-189.

de Sena, R.F., Moreira, R.F., José, H.F., 2008. Comparison of coagulants and coagulation aids for treatment of meat processing wastewater by column flotation. Biores. Technol. 99, 8221-8225.

Fahim, A.F., Fleita, D.H., Ibrahim, A.M., El-Dars, F.M.S., 2001. Evaluation of some methods for fish canning wastewater treatment. Water Air Soil Pollut. 127, 205-226.

Gómez, M., de la Rua, A., Garrálon, G., Plaza, F., Hontoria, E., Gómez, M.A., 2006. Urban wastewater disinfection by filtration technologies. Desalination 190, $16-28$.

Guo, M., Hu, H., Liu, W., 2009. Preliminary investigation on safety of post-UV disinfection of wastewater: bio-stability in laboratory-scale simulated reuse water pipelines. Desalination 239, 22-28.

Guo, M., Huang, J., Hu, H., Liu, W., 2011. Growth and repair potential of three species of bacteria in reclaimed wastewater after UV disinfection. Biomed. Environ. Sci. $24,400-407$
Hallmich, C., Gehr, R., 2010. Effect of pre- and post-UV disinfection conditions on photoreactivation of fecal coliforms in wastewater effluents. Water Res. 44, 2885-2893.

Hamoda, M.F., Al-Ghusain, I., Al-Mutairi, N., 2004. Sand filtration of wastewater for tertiary treatment and water reuse. Desalination 164, 203-211.

Hijnen, W.A.M., Beerendonk, E.F., Medema, G.J., 2006. Inactivation credit of UV radiation for viruses, bacteria and protozoan (oo)cysts in water: a review. Water Res. 40, 3-22.

Jin, X., Li, E., Lu, S., Qiu, Z., Sui, O. 2013. Coking wastewater treatment for industria reuse purpose: combining biological processes with ultrafiltration, nanofiltration and reverse osmosis. J. Environ. Sci. 25, 1565-1574.

Kuca, M., Szaniawska, D., 2009. Application of microfiltration and ceramic membranes for treatment of salted aqueous effluents from fish processing. Desalination 241, 227-235.

Liberti, L., Notarnicola, M., Petruzzelli, D., 2003. Advanced treatment for municipal wastewater reuse in agriculture. UV disinfection: parasite removal and byproduct formation. Desalination 152, 315-324.

Martin, C.J., Kartinen Jr., E.O., Condon, J., 1995. Examination of processes for multiple contaminant removal from groundwater. Desalination 102, 35-45.

Martín, M.A., González, I., Berrios, M., Siles, J.A., Martín, A., 2011. Optimization of coagulation-flocculation process for wastewater derived from sauce manufacturing using factorial design of experiments. Chem. Eng. J. 172 $771-782$.

Mavrov, V., Bélières, E., 2000. Reduction of water consumption and wastewater quantities in the food industry by water recycling using membrane processes. Desalination 131, 75-86.

Metcalf, L., Eddy, H.P., Tchobanoglous, G., Burton, F.I., 1991. Wastewater Engineering: Treatment, Disposal, Reuse. McGraw-Hill Companies, (New York).

Muthukumaran, S., Baskaran, K., 2013. Organic and nutrient reduction in a fish processing facility - a case study. Int. Biodeter. Biodeg. 85, 563-570.

Palenzuela Rollón, A., 1999. Anaerobic Digestion of Fish Processing Wastewaters with Special Emphasis on Hydrolysis of Suspended Solids. Wageningen Universiteit, Wageningen. Promotors : Prof.dr.ir. G. Lettinga, Prof. dr.ir. G.J. Alaerts, co-promotors Dr. G. Zeeman, Dr. H. J.Lubberding.

Paterniani, J.E.S., Conceição, C.H.Z., 2001. Utilização da pré-filtração e filtração lenta no tratamento de água para piscicultura. Rev. Ecossist. 26, 8-12.

Pérez-Gálvez, R., Guadix, E.M., Berge, J.P., Guadix, A., 2011. Operation and cleaning of ceramic membranes for the filtration of fish press liquor. J. Membr. Sci. 384 $142-148$.

Ranganathan, K., Kabadgi, S., 2011. Studies on feasibility of reverse osmosis (Membrane) technology for treatment of tannery wastewater. J. Environ. Protec. $2,37-46$

Rautenbach, R., Lim, T., 1996. High-pressure reverse osmosis and nanofiltration, a "zero discharge" process combination for the treatment of waste water with severe fouling/scaling potential. Desalination 105, 63-70.

Rautenbach, R., Mellis, R., 1995. Hybrid processes involving membranes for the treatment of highly organic/inorganic contaminated waste water. Desalination 101, 105-113.

Riaño, B., Molinuevo, B., García-González, M.C., 2011. Treatment of fish processing wastewater with microalgae-containing microbiota. Biores. Technol. 102 10829-10833.

Scholz, W.G., RougÉ, P., Bódalo, A., Leitz, U., 2005. Desalination of mixed tannery effluent with membrane bioreactor and reverse osmosis treatment. Environ. Sci. Technol. 39, 8505-8511.

Wang, J.P., Chen, Y.Z., Ge, X.W., Yu, H.Q. 2007. Optimization of coagulation-flocculation process for a paper-recycling wastewater treatment using response surface methodology. Colloids Surf. A: Physicochem. Eng. Asp. 302, 204-210.

Zufía, J., Aurrekoetxea, G., 2002. Integrated processing of fish canning industry wastewater. J. Aquat. Food Prod. Technol. 11, 303-315. 